\title{
Research on the Effects of Environmental Regulations on Industrial-Technological Innovation Based on Pressure Transmission
}

\author{
Mengqi Quan ${ }^{1}$, Quan Guo ${ }^{2, *}$, Qing Xia ${ }^{1, *}$ and Min Zhou ${ }^{1}$ \\ 1 School of Economics and Management, China University of Mining and Technology, Xuzhou 221116, China; \\ q13115210537@163.com (M.Q.); xzkdzm@163.com (M.Z.) \\ 2 School of Economics and Management, Suzhou Polytechinic Institute of Agriculture, Suzhou 215000, China \\ * Correspondence: gqteacher@cumt.edu.cn (Q.G.); betty_hellen@163.com (Q.X.)
}

check for updates

Citation: Quan, M.; Guo, Q.; Xia, Q.; Zhou, M. Research on the Effects of Environmental Regulations on Industrial-Technological Innovation Based on Pressure Transmission. Sustainability 2021, 13, 11010. https:// doi.org/10.3390/su131911010

Academic Editor: Luigi Aldieri

Received: 24 August 2021

Accepted: 2 October 2021

Published: 4 October 2021

Publisher's Note: MDPI stays neutral with regard to jurisdictional claims in published maps and institutional affiliations.

Copyright: (c) 2021 by the authors. Licensee MDPI, Basel, Switzerland. This article is an open access article distributed under the terms and conditions of the Creative Commons Attribution (CC BY) license (https:// creativecommons.org/licenses/by/ $4.0 /)$.

\begin{abstract}
This paper investigates the transmission of pressure between the public, relevant government departments, and industrial firms through the use of formal environmental regulations. The data include formal environmental regulations issued from 2005 to 2019 in 179 cities in 27 provinces in China. The intermediary effect model and the threshold effect model are used to carry out research studies on the relationships between public-participated environmental regulations, formal environmental regulations, and industrial-technological innovations. Results indicate that: (1) Pressure is transmitted between the public, and relevant government sectors and industries. For instance, public-participated environmental regulations pressure relevant government departments to apply strong formal environmental regulations on industrial sectors. (2) Labor and capital have a positive moderating effect on the effect of formal environmental regulations on industrial-technological innovations. (3) Both public-participated and formal environmental regulations promote industrialtechnological innovations. (4) There is a threshold effect in formal environmental regulations. For instance, when the intensity of public-participated environmental regulations is higher than 93, the role of formal environmental regulations in promoting industrial-technological innovation can be completely maximized.
\end{abstract}

Keywords: environmental regulation; pressure transmission; industrial-technological innovation; mediation effect; threshold effect

\section{Introduction}

With the rapid spread of information in modern society, there are increasingly higher degrees of information transparency as well as public participation in social events. In addition, rapid economic developments and more public access to more sophisticated technologies increase public requirements for quality of life as well as attention to social public welfare. At the same time, under the influence of both information expansion and improvement of the public's environmental knowledge, more people can better articulate a range of various environmental concerns and participate more actively in environmental protectionism [1].

In this context, most forms of public participation in environmental regulation are expressing opinions on environmental issues, supervising and supplementing to the government's environmental policies. Increasing instances of information disclosures and pollution reports can increase public attention to environmental health issues.

When public opinion on environmental protection issues increases, public demands are conveyed to the government through various channels. Thus, the government must respond to public opinion and accept environmental pressure from society by implementing more efficient environmental policies. This is because environmental regulations are primary modes of government intervention for achieving win-win situations in economic and environmental scenarios. 
One major source of pollution is the industrial sector, which is also under various types of environmental regulations. Moreover, more developments in the industrial sector result in increasingly serious levels of environmental pollution. For instance, in 2018, China ranked last in the Global Environmental Performance Index released jointly by Yale University and other institutions.

Meanwhile, because innovations for improving environmental technology have become an essential link between the environment and the economy, many believe that environmental governance is inevitable [2]. In this context, government intervention is critical [3] but environmental governance is both a governmental and a social responsibility. For instance, evaluating the effects of a single environmental regulation on innovation may lead to deviations in guiding practices of environmental policies and to practical difficulties in addressing issues [4]. Thus, extant research methods include comparisons of the effects of various environmental regulations and analyses of the synergy between these regulations.

In this study on environmental regulations with public participation, the focus is on (1) public attention to environmental issues, (2) pressures of public participation on the government, and (3) how such pressures promote industrial-technological innovation through the intermediary effect model. At the same time, this paper uses the threshold model to analyze how public-participated environmental regulations can exert different levels of pressure to influence the effect of formal environmental regulation. It is remarkable that there are many ways to measure public concern. This paper adopts the "Baidu Index" method, which calculates the public's attention to the keywords of the environment on the network.

There are limitations to this paper. The government regulators need not only be concerned with efficiency in decision making but also with concepts of equity and effectiveness. However, this paper only considers the efficiency in the decision making of government regulators. It is hoped that future research can break through this limitation.

\subsection{Pressures from Public-Participated Environmental Regulations Put on Relevant Government Departments}

Environmental regulations include formal policies that limit pollution emissions through environmental governance as well as exemplify social responsibility and environmental protection [5]. These include formal and informal environmental regulations [6]. For instance, relevant departments formulate formal environmental regulations that include tax standards, subsidy policies, and the like [7]. On the other hand, informal environmental regulations include information disclosure and environmental protection agreements among non-official groups and organizations [8], as well as public-participated environmental regulations.

At present, public participation is a focus of discussion in the field of environmental governance. This includes how public-participated environmental regulations supplement formal environmental regulations and supervise implementation of laws and regulations by relevant government departments, both of which are essential to achieve green and sustainable development [9].

Moreover, research shows how public participation motivates relevant departments to implement environmental regulations [10-12]. For instance, the public's environmentrelated concerns compel governments to strengthen supervision and governance, and provide services in response to appeals, complaints, letters, speeches, and the like. In addition, these departments can be motivated to effectively articulate, supervise, and improve implementation of environmental laws. As a result, bottom-to-bottom policy competition due to the maintenance of city interests can be avoided [13].

\subsection{Effects of Environmental Regulations on Industrial-Technological Innovation}

Academic discussion on the effects of environmental regulations on innovation mainly focuses on two aspects. One discussion point is that environmental regulations have a negative impact on technological innovation. For instance, environmental regulations have 
caused companies to increase costs to control pollution, particularly in industries where environmental costs account for a relatively large amount. They increase production costs, occupy innovation funds, and hinder technological innovations [14-16]. Another point of discussion is that environmental regulations can promote technological innovation. As the Porter Hypothesis points out, environmental regulations can stimulate enterprises to engage in production technology innovation and improve their production efficiency and, at the same time, make up for the cost of environmental protection $[17,18]$. Based on the Porter hypothesis, some scholars propose that systematic mandatory environmental regulations can stimulate business enthusiasm for environmental protection, thus encouraging progress in production technology and green innovation [19-21].

However, the Porter Hypothesis does not incorporate informal environmental regulation into the research framework. To fill this gap, future research can integrate the study of the effects of formal and informal environmental regulations on innovation into the framework. For instance, when Zhu et al. evaluated technological innovations in steel enterprises, they found that both mandatory and voluntary environmental regulations resulted in a positive effect on technological innovation [22]. In a related paper, Gonz'alez et al. posited that informal environmental regulations could awaken environmental awareness in social systems, gradually enhance innovation awareness in enterprises, and produce synergistic effects with formal regulations [23]. Moreover, Chege and Wang found that, unlike formal regulations, informal environmental regulations are not mandatory. However, the environmental knowledge that participants learned in related activities can promote the clean transformation of production, thereby increasing the positive effects of formal environmental regulations on innovation [24].

To reprise, the existing literature includes studies on the effects of informal environmental regulations on the implementation effectiveness of formal environmental regulations, as well as the effects of formal and informal environmental regulations on technological innovation. However, there is a lack of focus on the "pressure" effects of informal environmental regulations on formal environmental regulations, as well as on the effects of this force on innovation through the transmission of formal environmental regulations.

\section{Theory and Hypotheses}

\subsection{Hypotheses}

During the expansion period of industrial economies, industrial production continued accelerating to meet planning and operating targets. This, in turn, resulted in a high volume of environmental pollutants [25] due to massive discharges of soot and industrial wastewater. Now, the public is more aware of the deterioration of environmental quality and the adverse effects on their health and lives [26], and thus there is increasingly widespread attention to environmental issues [27].

The main platforms for public participation in environmental issues include news reports, petitions, and expressing opinions to shape public opinion [28], so as to pressure relevant government departments and compel governments to address environmental issues [13]. In the context of increasing calls for environmental protection, relevant government departments act, to some extent, as the bridges between the public's environmental awareness and the industrial enterprises. In this regard, these departments issued measures to control pollution and regulate industrial production processes.

Based on the above analysis that there is transmission of pressures from public to relevant departments and then to industrial enterprises, the first hypothesis is proposed:

Hypothesis (H1). The public exerts pressure on relevant government departments by expressing opinions that compel relevant departments concerned with environmental issues. Government departments implement formal environmental regulations to transfer these pressures to industrial sectors. 
The most fundamental aspect of environmental governance is to control emissions. In this context, industrial enterprises are subjected to compulsory taxation or subsidies, to reduce pollutant emissions that can increase average production costs that are not conducive to improving profits and efficiency.

In this scenario, the need to increase revenues requires technological innovation for producing green and high value-added products. For instance, after internal evaluation and decision making, industrial enterprises weigh the pros and cons according to their own performance targets and decide whether to carry out technological innovation or to escape the pressures in other ways. However, when benefits outweigh costs, companies will choose to carry out technological innovation.

To reprise, the industrial sector is composed of various industrial enterprises. Thus, for the entire industrial system, it can be considered that the implementation of formal and informal environmental regulations can promote technological innovations and improve industrial technology innovations' speed and quality [29].

Three hypotheses are proposed based on the above analysis of environmental regulations and industrial innovation:

Hypothesis (H2). Public-participated environmental regulations can positively influence industrialtechnological innovation.

Hypothesis (H3). Formal environmental regulations have a positive impact on industrialtechnological innovation.

Hypothesis (H4). Formal environmental regulations have a mediating effect between publicparticipated environmental regulations and industrial-technological innovation.

As noted, both public-participated and formal environmental regulations are external incentives for spurring technological innovations in industries. At the same time, most technological innovation factors are related to economics. For instance, according to the theory of endogenous economic growth, labor factors [30] and capital factors [31] are necessary for enterprises to engage in technological innovation. Here, enterprises profit due to the surplus value created by labor, all of which are driven by capital elements. These fundamental elements of internal business operations inevitably affect technological innovations of industrial enterprises.

Moreover, this influence is not independent; a compound influence of internal factors is superimposed on external factors that affect industrial-technological innovations. To reprise, labor and capital can influence the effects of formal environmental regulations on industrial-technological innovations.

H5 is proposed based on the analysis of internal incentives for technological innovations:

Hypothesis (H5). Labor and capital exert a moderating effect on how formal environmental regulations influence industrial-technological innovations.

Research indicates a non-linear relationship between environmental regulation and technology innovation [32], a point of view supported in this study. For instance, under various levels of intensity of public-participated environmental regulations, formal environmental regulations have different effects on industrial-technological innovation. That is to say, under different pressure levels, the formal environmental regulations implemented by government departments have different effects on industrial-technological innovation $[33,34]$.

The influences that formal environmental regulation has on innovations depend on the intensity of the pressure on relevant departments from public participation. Combined with the above analysis, H1 posits that relevant departments issue and execute environmental regulations that transfer public pressure to the industrial sector. $\mathrm{H} 4$ posits that 
formal environmental regulations are an intermediary variable between public-participated environmental regulations and industrial-technological innovation.

Based on $\mathrm{H} 1$ and $\mathrm{H} 4$, it can be deduced that industrial-technological innovation is not only directly affected by the force of formal environmental regulations but also by the force of public-participated environmental regulations that are transmitted through formal environmental regulations. Moreover, it can be further assumed that the non-linear characters of the effects of formal environmental regulations on industrial-technological innovation need to be expressed through the intensity characteristics of public-participated environmental regulations.

Based on the analysis of non-linear relationship between formal environmental regulations and technological innovations, $\mathrm{H} 6$ is proposed.

Hypothesis (H6). The influence of formal environmental regulations to industrial-technological innovation is non-linear, and the effects are directly related to the intensity of public-participated environmental regulations.

In this section, the hypotheses were deduced step by step through the analysis of the literature. In the next paragraphs, the hypotheses are analyzed theoretically and then verified by empirical analysis.

Table 1 is an explanation of the hypotheses.

Table 1. Explanation of hypotheses.

\begin{tabular}{ccc}
\hline Hypotheses & Explanation & Involved Indicators \\
\hline H1 & $\begin{array}{c}\text { Environmental pressure transmitted from the public } \\
\text { to relevant departments, and from relevant } \\
\text { departments to industrial sector. } \\
\text { Pres has positive influence on } R D .\end{array}$ & pres, cres, $R D$ \\
H2 & Cres has positive influence on $R D$. & pres, $R D$ \\
H3 & Cres is a mediating variable between pres and $R D$. & pres, cres, $R D$ \\
H4 & Lab and invest exert a moderating effect on how cres & influences $R D$. \\
H5 & There is a threshold effect in cres. & cres, pres, $R D$ \\
H6 & &
\end{tabular}

\subsection{Theoretical Analysis}

2.2.1. Transmission of Environmental Pressure between Subjects

In the environmental pressure transmission chain, the public is the source of pressure. For instance, the public feels the degradation of the environment and realizes the negative effects of industrial pollution on public welfare. As a result, the public acts to express its concerns and defend its interests and demands through legitimate means.

In this scenario, public opinion is transmitted through various websites and communication platforms to relevant government departments. As a result, the public elicits increased attention from the government to environmental issues.

To reprise, after gauging the intensity of public pressure, government departments increase their focus and effort to improve environmental conditions. For instance, they issue formal environmental regulations and measures such as taxation, subsidies, increased supervision, investments, and governance. Since most pollutants are from the industrial sector, this sector is the main target of environmental regulation. In other words, the government uses formal environmental regulations to apply pressure on the industrial sector. Thus, public environmental pressure is directed at the industrial sector through formal environmental regulations. The process is shown in Figure 1. 


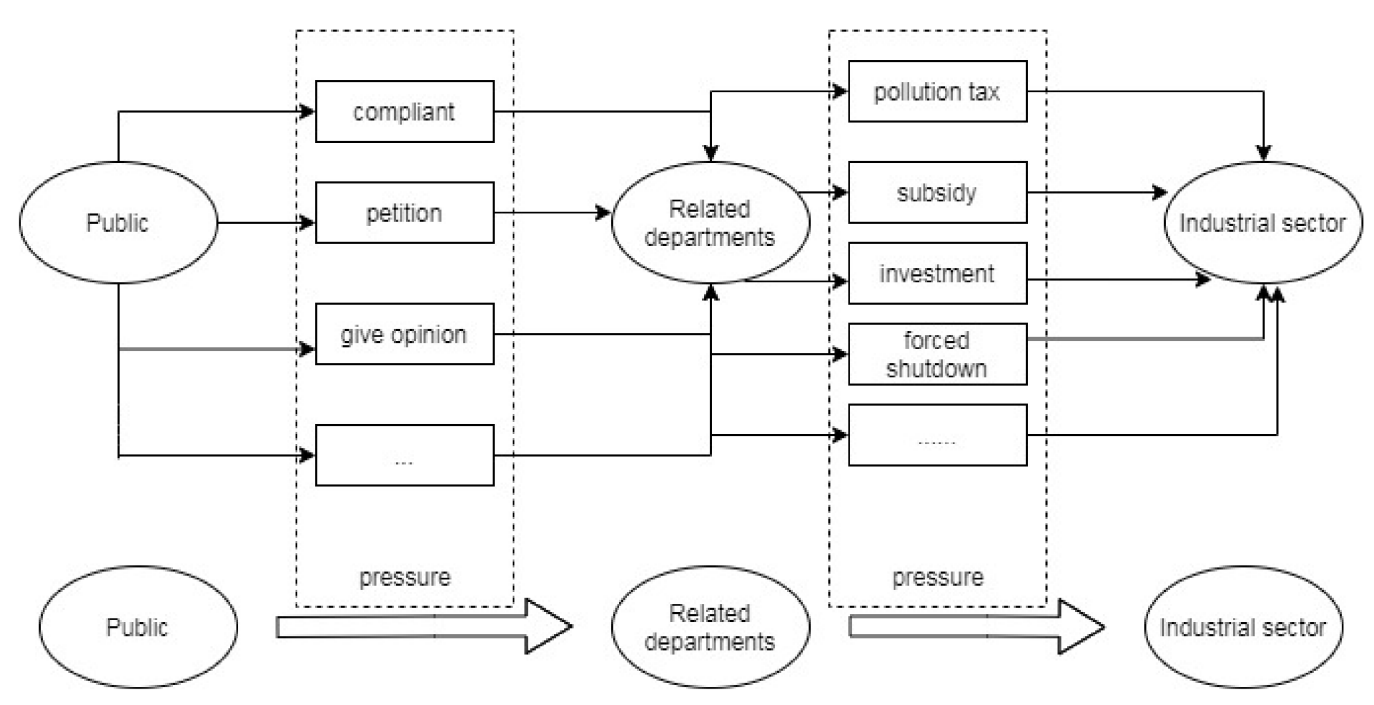

Figure 1. Environmental pressure transmission.

\subsubsection{Environmental Regulations Promote Industrial-Technological Innovation}

Assume that the total production cost of an industrial sector enterprise is $T C(x)$. When the output is fixed, its production $\operatorname{cost} C(x)$ changes with the change of $x$, and $x$ is the emission of pollutants. Thus, when $x$ increases, the production cost decreases. Therefore, $M C(x)$ is negative and $C(x)$ is a monotonically decreasing function. If a pollution fee of $p$ per unit price is levied on emissions, then the total cost is $T C(x)=C(x)+p x$.

Since $T C(x)$ is greater than $C(x)$, the levy of sewage charges will increase the cost of industrial enterprises, and the increase in costs will decrease profits. Further detailed, the production $\operatorname{cost} C(x)$ is decomposed into a variable cost $V(y, x)$ and a fixed $\operatorname{cost} F C$, where $y$ is the quantity of the product produced. Then the total cost is: $T C(y, x)=V(y, x)+p x+F C$.

Assuming a fixed relationship between production and output, increased production means increased pollution. That is, $x=e y$, where $e$ is the constant coefficient between the two. In this case, the formula can be expressed as $T C(y, e y)=V(y, e y)+$ pey $+F C$. It can be further simplified as $T C(y)=V(y)+$ pey $+F C$, and marginal cost can be expressed as $M C(y)=M V(y)+p e$.

If relevant departments adopt a subsidy policy, the following situation would appear: consider the rate of subsidies for $s$, an industrial enterprise's expected pollution emission for $x^{\prime}$, in the case in which subsidized enterprises receive subsidies for losses; then, in order to obtain subsidies to reduce emissions to $x$ the enterprise will get $s\left(x^{\prime}-x\right)$, the total cost would be $T C(y)=V(y)+F C-s\left(x^{\prime}-x\right)=V(y)+s e y+\left\{F C-s x^{\prime}\right\}$ and the marginal cost can be obtained as $M C(y)=M V(y)+$ se.

The above formula indicates that, assuming $s=p$, the marginal cost of levying a pollution tax is the same as an emission reduction subsidy. Thus, the taxation and subsidy can increase the marginal cost and create the same result. Therefore, in the short term, even if there is no additional pollution fee, a decrease in pollutant discharges will still increase costs and decrease profits.

In the long run, however, environmental regulations can stimulate technological innovations in industrial firms. For instance, suppose that enterprise i and enterprise $j$ are homogeneous, and the technological innovation index of enterprise $j$ is Tj. Assume that the government provides enterprises with initial emission permits of unit $b$, where measures are taken for the part that exceeds the permits, and the regulatory intensity is $t$. Thus, the intensity of an enterprise's technology update is $K$, and the optimal plan for enterprise $j$ can be expressed as $\min C j(x j)+t(x j-b)+K j$ and the optimal plan for firm $i$ is $\min C i(x i)+t(x i-b)$. 
In this scenario, the optimal emission of enterprise $j$ is $x j^{*}(t, T j)=\left\{x j / C j^{\prime}(x j)+t=0\right\}$, while the optimal emission of enterprise $i$ is $x i^{*}(t)=\left\{x i / C i^{\prime}(x i)+t=0\right\}$.

Thus, the optimal emission of technological innovations in industrial enterprises can be expressed as $x j^{*}<x i^{*}$. In this case, the benefits brought by technological innovation are the optimal planning equation of enterprise $j$ and the optimal planning equation of enterprise $i$ subtracted to obtain $E T=C i\left(x i^{*}\right)-C j\left(x j^{*}\right)+t\left(x i^{*}-x j^{*}\right)-K j$.

When $E T \geq 0$, the enterprise will choose to carry out technological innovation. In order to enable the enterprise to reach the optimal state, the partial derivatives of $x j^{*}$ and $x i^{*}$ of this formula are obtained, respectively, so that $C i\left(x i^{*}\right)=C j\left(x j^{*}\right)=-t$. Substitute it in the above equation and find its partial derivative with respect to $t: \partial E T / \partial t=x i^{*}-x j^{*}>0$.

Therefore, from a micro perspective, it can be concluded that environmental regulations can stimulate technological innovations in industrial enterprises. Since various industrial enterprises comprise the industrial sector, environmental regulations increase the industrial enterprises that engage in technological innovations, which can improve innovative technology in the entire industrial sector.

The preceding paragraphs present a theoretical discussion of related issues. Specific conclusions also need to be drawn via empirical research.

\section{Research Design and Data Collection}

\subsection{Variable Selection}

Explained variable: Technological innovation level $(R D)$ : There are two main methods for measuring technological innovation level: One is to measure its input process, and the other is to measure its output results [35,36]. This study uses the first method, which uses the following formula to measure the level of technological innovation: internal R\&D expenditure of industrial enterprises above designated size/industrial output value.

Explanatory variable: Public-participated environmental regulations (pres): This measures the degree of people's concern and supervision of environmental issues in the region. In this study, the intensity of public-participated environmental regulation is measured by the attention of the phrase "environmental pollution" in the Baidu Index [37].

Intermediary variable: Formal environmental regulations (cres): For easy access to data, this study uses the completion of industrial pollution control investment in each region to calculate formal environmental regulations [38].

Control variables: The level of economic development $(p g d p)$. Per capita income can measure the level of local economic development [39]. In areas with high per capita disposable income, there may be more patent activities, a relatively high level of industrial structure, and more abundant and convenient supporting resources and infrastructures that help attract talents and maximize efficiency, which can improve levels of industrial innovation.

Population density $(p d s t)$. In the article, population density can be calculated by the formula: total population/total area of a city. Generally, in areas with high population density, the proportion of people with higher education will also be relatively large. The higher the proportion of higher education groups, the more they can strengthen human capital and improve innovation levels in industrial systems [40].

Information technology competence (inf). This paper uses the telecommunication service income to measure the information technology competence of the city. For instance, to a certain extent, improvements in the information technology competence will help change the standard operating modes of enterprises, improve efficiency, promote communication between personnel or enterprises, and open avenues for innovation in business enterprises. In other words, the development of information technology competence provides a certain incentive effect that can improve technological innovation in business enterprises.

The level of opening up (open). This article focuses on the actual use of foreign capital to measure a city's opening-up level in terms of foreign trade and exchange. The level of opening to the outside world is a double-edged sword in the context of urban industrial innovation. For instance, to some extent, cooperation with foreign investors can introduce 
advanced foreign technology and talents, promote bilateral exchanges, stimulate innovation vitality, and promote technological innovation. On the other hand, in the process, cities can suffer from high levels of industrial pollutants that can result in the pollution haven effect. At the same time, foreign investments can crowd out local investments, restrict development spaces for local enterprises, and negatively affect technological innovations in local enterprises [41].

\section{Adjustment variables:}

Labor factor (lab). To measure the labor factor, this paper uses the size of the industrial workforce. As mentioned, the labor factor and capital factor are critical elements for industrial enterprises to engage in technological innovation [42].

Capital factor (invest). To measure the capital factor, this study uses industrial investments in fixed assets. Adjustment variables take the effects of city size into account to verify conclusions.

\subsection{Mediating Effect Model}

In this model, the stepwise regression method is used to measure the influence of public-participated environmental regulations on industrial-technological innovations through the mediating effects of formal environmental regulations:

$$
\begin{gathered}
\operatorname{RD}_{i, t}=\alpha_{0}+\alpha_{1} \text { pres }_{i, t}+\alpha_{2} \operatorname{lnggdp}_{i, t}+\alpha_{3} \operatorname{lnpdst}_{i, t}+\alpha_{4} \operatorname{lninf}_{i, t}+\alpha_{5} \operatorname{lnopen}_{i, t}+\varepsilon 1_{i, t}, \\
\operatorname{lncres}_{i, t}=\beta_{0}+\beta_{1} \text { pres }_{i, t}+\beta_{2} \operatorname{lnpgdp}_{i, t}+\beta_{3} \operatorname{lnpdst}_{i, t}+\beta_{4} \operatorname{lninf}_{i, t}+\beta_{5} \operatorname{lnopen}_{i, t}+\varepsilon 2_{i, t}, \\
\operatorname{RD}_{\mathrm{i}, t}=\lambda_{0}+\lambda_{1} \text { pres }_{i, t}+\lambda_{2} \operatorname{lncres}_{i, t}+\lambda_{3} \operatorname{lnpgdp}_{i, t}+\lambda_{4} \operatorname{lnpdst}_{i, t}+\lambda_{5} \operatorname{lninf}_{i, t}+\lambda_{6} \operatorname{lnopen}_{i, t}+\varepsilon 3_{i, t,}
\end{gathered}
$$

\subsection{Moderating Effect Model}

The moderating effect model is used to explore the effect of internal incentives for technological innovations:

$$
\begin{aligned}
\mathrm{RD}_{i, t}=\gamma_{0}+\gamma_{1} \text { pres }_{i, t} & +\gamma_{2} \operatorname{lncres}_{i, t} \times \operatorname{lnlab}_{i, t}+\gamma_{3} \operatorname{lnggdp_{i,t}}+\gamma_{4} \operatorname{lnpdst}_{i, t} \\
+ & \gamma_{5} \operatorname{lninf}_{i, t}+\gamma_{6} \operatorname{lnopen}_{i, t}+\varepsilon_{i, t} \\
\mathrm{RD}_{i, t}=\theta_{0}+\theta_{1} \text { pres }_{i, t} & +\theta_{2} \operatorname{lncres}_{i, t} \times \operatorname{lninvest}_{i, t}+\theta_{3} \operatorname{lnggdp}_{i, t}+\theta_{4} \operatorname{lnpdst}_{i, t} \\
& +\theta_{5} \operatorname{lninf}_{i, t}+\theta_{6} \operatorname{lnopen}_{i, t}+\varepsilon_{i, t} \\
\mathrm{RD}_{i, t}=\psi_{0}+\psi_{1} \text { pres }_{i, t}+\psi_{2} \operatorname{lncres}_{i, t} \times \operatorname{lnlab}_{i, t} \times \operatorname{lninvest}_{i, t}+\psi_{3} \operatorname{lnggdp}_{i, t}+\psi_{4} \operatorname{lnpdst}_{i, t} & \\
+ & \psi_{5} \operatorname{lninf}_{i, t}+\psi_{6} \operatorname{lnopen}_{i, t}+\varepsilon_{i, t}
\end{aligned}
$$

\subsection{Threshold Effect Model}

The threshold effect model can be used to measure the threshold effects of formal environmental regulations and public-participated environmental regulations on industrialtechnological innovations and the effects of various intensity ranges, which can provide certain reference points in policymaking:

$$
\begin{aligned}
& \operatorname{RD}_{i, t}=\eta_{0}+\eta_{1} \operatorname{lncres}_{i, t} \times \mathrm{I}\left(\text { pres }_{i, t} \leq \mathrm{a}_{1}\right)+\eta_{2} \operatorname{lncres}_{i, t} \times \mathrm{I}\left(\mathrm{a}_{1}<\text { pres }_{i, t} \leq \mathrm{a}_{2}\right)+\ldots \\
&+\eta_{3} \operatorname{lncres}_{i, t} \times \mathrm{I}\left(\mathrm{a}_{2}<\text { pres }_{i, t} \leq \mathrm{a}_{3}\right)+\eta_{4} \operatorname{lnpgdp}_{i, t}+\eta_{5} \operatorname{lnpdst}_{i, t} \\
&+\eta_{6} \operatorname{lninf}_{i, t}+\eta_{7} \operatorname{lnopen}_{i, t}+\varepsilon_{i, t}
\end{aligned}
$$

In the threshold effect model, $i$ denotes the city $(i=1,2,3, \ldots, 179), t$ denotes the time $(t=1,2,3, \ldots, 15)$, and $\varepsilon 1_{i, t}, \varepsilon 2_{i, t}, \varepsilon 3_{i, t}, \varepsilon_{i, t}$ represent the residual effects.

Table 2 lists the definition of the variables. 
Table 2. Definitions of the variables in the model.

\begin{tabular}{|c|c|c|}
\hline Variables & Definition & Unit \\
\hline Technological innovation level $(R D)$ & $\begin{array}{l}\text { Internal R\&D expenditure of industrial enterprises } \\
\text { above designated size/industrial output value }\end{array}$ & - \\
\hline Public-participated environmental regulations (pres) & $\begin{array}{c}\text { Frequency of the word "environmental pollution" } \\
\text { in the Baidu Index }\end{array}$ & - \\
\hline Formal environmental regulations (cres) & $\begin{array}{l}\text { Completion of industrial pollution control investment } \\
\text { in each region }\end{array}$ & 10,000 yuan \\
\hline The level of economic development (pgdp) & Per capita income & 10,000 yuan \\
\hline Population density $(p d s t)$ & Total population/total area of a city & $\begin{array}{l}\text { 10,000 people per } \\
\text { square kilometer }\end{array}$ \\
\hline $\begin{array}{l}\text { Information technology competence (inf) } \\
\text { The level of opening up (open) }\end{array}$ & $\begin{array}{l}\text { Telecommunication service income } \\
\text { The actual use of foreign capital }\end{array}$ & $\begin{array}{l}10,000 \text { yuan } \\
10,000 \text { yuan }\end{array}$ \\
\hline Labor factor $(l a b)$ & The size of the industrial work force & $\begin{array}{l}\text { persons in a } \\
\text { measurement unit }\end{array}$ \\
\hline Capital factor (invest) & The industrial investment in fixed assets & 10,000 yuan \\
\hline
\end{tabular}

\subsection{Data Source}

This study analyzed data from 179 cities in 27 provinces in China (excluding Tibet, Qinghai, Guizhou, Hainan, Hong Kong, Macao, and Taiwan) from 2005 to 2019. The R\&D internal expenditures of industrial enterprises above designated the sizes in these areas, which come from The Statistical Yearbook of Chinese Cities, The Statistical Yearbook of China Science, and Technology and the statistical yearbook of each city. Data on the completion of industrial pollution control investment comes from the statistical yearbooks of each city and province as well as the China Environmental Statistical Yearbook. Data on per capita income, population density, telecommunications service income, and the actual use of foreign capital are all from The Statistical Yearbook of Chinese Cities and the statistical yearbooks of each city.

\subsection{Description of Variables}

The descriptive statistics of variables are shown in Table 3.

Table 3. Descriptive statistics of variables.

\begin{tabular}{cccccc}
\hline Variables & $\boldsymbol{N}$ & Mean & Sd & Min & Max \\
\hline RD & 2670 & 2.708 & 3.379 & 0.00191 & 50.40 \\
Pres & 2670 & 24.13 & 28.80 & 0 & 190 \\
Cres & 2670 & 25,717 & 42,157 & 760.8 & 555,609 \\
Pgdp & 2670 & 2.301 & 1.092 & 0.573 & 7.385 \\
Pdst & 2670 & 0.0522 & 0.0347 & 0.000537 & 0.276 \\
Inf & 2670 & 531,406 & $1.202 \times 10^{6}$ & 12,274 & $2.816 \times 10^{7}$ \\
Open & 2670 & 679,028 & $1.464 \times 10^{6}$ & 19.80 & $2.034 \times 10^{7}$ \\
Lab & 2670 & 633,961 & 931,428 & 63,800 & $9.869 \times 10^{6}$ \\
Invest & 2670 & $1.507 \times 10^{6}$ & $1.786 \times 10^{7}$ & 486,569 & $1.863 \times 10^{8}$ \\
\hline
\end{tabular}

\section{Results and Discussions}

\subsection{Mediating Effects of Formal Environmental Regulations}

A unit root test was performed on each variable. Table 4, shows the results where there is no unit root in each variable. Moreover, the VIF value of each explanatory variable is much less than 10 , which indicates that there is no collinearity. 
Table 4. Unit root test results.

\begin{tabular}{ccc}
\hline Variables & Adjusted $\mathbf{t}^{*}$ & VIF \\
\hline RD & $-1.6336^{* 1}$ & \\
Pres & $-14.9125^{* * * 1}$ & 2.94 \\
Lncres & $-15.3842^{* * *}$ & 2.8 \\
Lnpgdp & $-13.0304^{* * *}$ & 2.21 \\
Lnpdst & $-2.1814^{* * 1}$ & 2.12 \\
Lninf & $-19.1911^{* * *}$ & 1.67 \\
Lnopen & $-15.4869^{* * *}$ & 1.27 \\
Er & $-5.924^{* * *}$ & \\
\hline
\end{tabular}

Note: ${ }^{* *} p<1 \%,{ }^{* *} p<5 \%,{ }^{*} p<10 \%$. The same below.

Table 5 shows the regression results of Models 1, 2, and 3 obtained through stepwise regression. The results indicate that Hypothesis 4 is true, confirming that formal environmental regulations have a mediating effect between public-participated environmental regulations and industrial-technological innovation. For instance, Model 1 indicates that, as a key participant in environmental protection, the public's focus and attention on environmental issues have a very significant and positive effect on industrial innovations.

Table 5. Results of model regression.

\begin{tabular}{|c|c|c|c|c|c|c|}
\hline \multirow{2}{*}{ Variables } & Model 1 & Model 2 & Model 3 & Model 4 & Model 5 & Model 6 \\
\hline & RD & lncres & RD & RD & RD & RD \\
\hline Pres & $\begin{array}{c}0.043^{* * *} \\
(14.01)\end{array}$ & $\begin{array}{c}0.013^{* * *} \\
(16.05)\end{array}$ & $\begin{array}{c}0.040^{* * *} \\
(12.53)\end{array}$ & $\begin{array}{l}0.037^{* * *} \\
(10.95)\end{array}$ & $\begin{array}{c}0.043^{* * *} \\
(13.06)\end{array}$ & $\begin{array}{c}0.039 * * * \\
(11.47)\end{array}$ \\
\hline Lncres & & & $\begin{array}{c}0.219^{* * *} \\
(2.90)\end{array}$ & & & \\
\hline \multirow{2}{*}{ Variables } & Model 1 & Model 2 & Model 3 & Model 4 & Model 5 & Model 6 \\
\hline & RD & lncres & RD & RD & RD & RD \\
\hline lncres $\times$ lnlab & & & & $\begin{array}{c}0.023^{* * *} \\
(4.76)\end{array}$ & & \\
\hline lncres $\times$ lninvest & & & & & $\begin{array}{l}0.002 \\
(0.46)\end{array}$ & \\
\hline lncres $\times$ lnlab $\times$ lninvest & & & & & & $\begin{array}{c}0.001^{* * *} \\
(2.65)\end{array}$ \\
\hline Lnpgdp & $\begin{array}{c}0.534^{* * *} \\
(3.63)\end{array}$ & $\begin{array}{c}-0.249^{* * *} \\
(-6.6)\end{array}$ & $\begin{array}{c}0.589^{* * *} \\
(3.98)\end{array}$ & $\begin{array}{c}0.657^{* * *} \\
(4.42)\end{array}$ & $\begin{array}{c}0.526^{* * *} \\
(3.54)\end{array}$ & $\begin{array}{c}0.52^{* * *} \\
(3.54)\end{array}$ \\
\hline Lnpdst & $\begin{array}{c}-0.050 * * * \\
(-0.58)\end{array}$ & $\begin{array}{c}0.088^{* * *} \\
(3.97)\end{array}$ & $\begin{array}{l}-0.070 \\
(-0.81)\end{array}$ & $\begin{array}{l}-0.096 \\
(-1.11)\end{array}$ & $\begin{array}{l}-0.053 \\
(-0.61)\end{array}$ & $\begin{array}{l}-0.071 \\
(-0.82)\end{array}$ \\
\hline Lninf & $\begin{array}{c}0.384^{* * *} \\
(4.24)\end{array}$ & $\begin{array}{c}0.313^{* * *} \\
(13.44)\end{array}$ & $\begin{array}{c}0.316^{* * *} \\
(3.37)\end{array}$ & $\begin{array}{l}0.209^{* *} \\
(2.15)\end{array}$ & $\begin{array}{c}0.371^{* * *} \\
(3.92)\end{array}$ & $\begin{array}{c}0.284^{* * * *} \\
(2.89)\end{array}$ \\
\hline Lnopen & $\begin{array}{c}0.0932 * * \\
(2.01)\end{array}$ & $\begin{array}{c}0.163^{* * *} \\
(13.74)\end{array}$ & $\begin{array}{l}0.057 \\
(1.20)\end{array}$ & $\begin{array}{l}0.024 \\
(0.49)\end{array}$ & $\begin{array}{l}0.086^{*} \\
(1.74)\end{array}$ & $\begin{array}{l}0.046 \\
(0.92)\end{array}$ \\
\hline $\mathrm{C}$ & $\begin{array}{l}-4.82 * * * \\
(-4.14)\end{array}$ & $\begin{array}{c}3.750^{* * *} \\
(12.54)\end{array}$ & $\begin{array}{c}-5.641^{* * *} \\
(-4.71)\end{array}$ & $\begin{array}{c}-4.683^{* * *} \\
(-4.04)\end{array}$ & $\begin{array}{c}-4.834^{* * *} \\
(-4.15)\end{array}$ & $\begin{array}{l}-4.3^{* * *} \\
(-3.64)\end{array}$ \\
\hline $\mathrm{R}^{2}$ & 0.286 & 0.547 & 0.289 & 0.292 & 0.286 & 0.289 \\
\hline $\mathrm{F}$ & $213.7^{* * *}$ & $643.91^{* * *}$ & $179.98^{* * *}$ & $183.3^{* * *}$ & $178.06^{* * *}$ & $179.65^{* * *}$ \\
\hline$N$ & 2670 & 2670 & 2670 & 2670 & 2670 & 2670 \\
\hline
\end{tabular}

Table A1 (see Appendix A) indicates that higher levels of economic development improve industrial innovation abilities. For instance, regions with a higher level of economic development have relatively advanced forms of production and industrial structure. At the same time, they also pay more attention to the role of innovation in local developments. In this context, cities such as Suzhou and Nanjing have more complete innovation incentives and patent incubation policies that can provide better support for technological innovation.

On the other hand, high population density is not conducive to industrial-technological innovation. For instance, a high population can squeeze urban infrastructures, decline social efficiency, increase pressure, and crowd out of talent, all of which can restrict, divert, or kill off industrial innovations.

As mentioned, a high level of information technology competence can exert positive effects on technological innovations in industrial systems. For instance, better information technology competence helps improve efficiency in business operations, strengthen 
communication between employees, and transform knowledge into achievements. All of these are conducive to technological innovations in industrial enterprises and improve innovation levels throughout the entire industrial system.

Similarly, to some extent, improved levels of trade exchange and openness introduce foreign capital, foreign technology and talents, accelerate collision and exchange of knowledge, and contribute to increasing levels of business and industrial innovations.

\subsection{Pressure from Public-Participated Environmental Regulations}

In Table 5, Model 2 is used to verify the pressure effect of public participation in environmental regulations on relevant departments. The regression results indicate a positive correlation between the two, with a pressure coefficient of 0.013 . In other words, every one-unit increase in the intensity of pressure from public-participated environmental regulation increases the intensity of formal environmental regulation by 0.013 units. This confirms that Hypothesis 1 is true.

In addition, there is a negative relationship between the level of urban economic development and formal environmental regulations. This can be attributed to the main driving force of China's economic development, which still prioritizes the industrial sector, as well as the status quo of the exchange of pollution for development, which is still the mode of economic growth in many cities where environmental regulations are relaxed to encourage economic development. Moreover, information technology competence and openness are positively correlated with formal environmental regulations.

\subsection{Moderating Effects of Labor and Capital on Industrial Innovation}

The regression results of Model 4 in Table 5 indicate that, at a 1\% significance level, the interaction of formal environmental regulations and the labor force has positive effects on industrial-technological innovation. For instance, assuming that the intensity of formal environmental regulations remains stable, the industrial-technological innovation level increases by $0.023 \%$ for every $1 \%$ increase of the labor force. Similarly, assuming a stable total labor force, every $1 \%$ increase in the intensity of environmental regulations increases the level of industrial innovation by $0.023 \%$. Model 5 indicates that the moderating effect of capital is not significant. On the other hand, the interactions of the three variables in Model 6 have significantly positive effects on the levels of industrial-technological innovations. However, under the two moderating variables, the effects of formal environmental regulations on industrial-technological innovations is significantly reduced.

The regression results of Models 4, 5, and 6 indicate that Hypothesis 5 is true.

The preceding regression results indicate that the coefficients $\alpha 1, \beta 1$, and $\lambda 2$ in Equations (1), (2), and (3) are all significant, indicating a preliminary conclusion that a mediating effect exists. In addition, the Sobel test and bootstrap test were subsequently performed. The Sobel test results indicate that the mediating effect is significant. Moreover, the bootstrap test results also indicate that cres is a very significant mediating variable. After the bootstrap test was repeated 1000 times, the data obtained is shown in Table 6, where the $p$-value of the indirect effect is 0.002 , and the confidence interval is [0.003, 0.135], excluding 0 , which indicates that the indirect effect is significant.

Table 6. Bootstrap test.

\begin{tabular}{|c|c|c|c|c|c|c|}
\hline & $\begin{array}{l}\text { Observed } \\
\text { Coed }\end{array}$ & $\begin{array}{l}\text { Bootstrap } \\
\text { std.Err. }\end{array}$ & $\mathbf{Z}$ & $p>|z|$ & \multicolumn{2}{|c|}{$\begin{array}{c}\text { Normal-Based } \\
{[95 \% \text { conf. Internal] }}\end{array}$} \\
\hline _bs_1 & 0.0082795 & 0.0026836 & 3.09 & 0.002 & 0.0030198 & 0.0135392 \\
\hline bs_2 & 0.0527429 & 0.0060999 & 8.65 & 0.000 & 0.0407873 & 0.0646986 \\
\hline
\end{tabular}

Number of obs = 2670; replications = 1000;_bs_1: r(ind_eff); bs_2: r(dir_eff). 
4.4. Influence of Formal Environmental Regulations on Industrial Innovation under the Pressure of Public Participation

The regression and test results in the preceding sections indicate that an intermediary effect exists between public-participated environmental regulations, formal environmental regulations, and industrial-technological innovations, and that public-participated environmental regulations exert pressure on relevant government departments, thus promoting the implementation of formal environmental regulations.

In this section, the threshold effect is used to determine the level of public-participated environmental regulations that can promote the full play of the roles of formal environmental regulation. For instance, Table 7 indicates that public-participated environmental regulations have a double-threshold effect. Here, the single-threshold value passed the $1 \%$ significance test, while the double-threshold value passed the $5 \%$ significance test.

Table 7. Threshold effect test.

\begin{tabular}{cccccccccc}
\hline Variables & Threshold & RSS & MSE & Fstat & Prob & Crit10 & Crit5 & Crit1 & BS \\
\hline \multirow{2}{*}{ pres } & Single & 8835.09 & 3.33 & 64.36 & 0.0000 & 23.53 & 32.01 & 44.98 & 300 \\
& Double & 8746.55 & 3.29 & 26.88 & 0.0333 & 19.46 & 24.23 & 41.07 & 300 \\
\hline
\end{tabular}

Table 8 indicates that formal environmental regulations have different promotion effects on industrial-technological innovation under different intensities of public-participated environmental regulations.

Table 8. Threshold regression results.

\begin{tabular}{|c|c|}
\hline Variables & RD \\
\hline lncres*I (pres $\leq 14)$ & $\begin{array}{l}0.025 \\
(0.3)\end{array}$ \\
\hline lncres ${ }^{*} \mathrm{I}(14<$ pres $\leq 93)$ & $\begin{array}{l}0.091 \\
(1.09)\end{array}$ \\
\hline lncres*I (93 < pres) & $\begin{array}{c}0.256^{* * *} \\
(3.01)\end{array}$ \\
\hline $\operatorname{lnpgdp}$ & $\begin{array}{l}1.124^{* * *} \\
(8.84)\end{array}$ \\
\hline lnpdst & $\begin{array}{l}1.189 * * \\
(2.06)\end{array}$ \\
\hline $\operatorname{lninf}$ & $\begin{array}{l}0.111 \\
(1.10)\end{array}$ \\
\hline lnopen & $\begin{array}{l}-0.215^{* * *} \\
(-4.22)\end{array}$ \\
\hline $\mathrm{C}$ & $\begin{array}{l}6.256^{* *} \\
(2.52)\end{array}$ \\
\hline $\mathrm{R}^{2}$ & 0.18 \\
\hline $\mathrm{F}$ & $20.84^{* * *}$ \\
\hline
\end{tabular}

For instance, when the intensity of public-participated environmental regulation is lower than 14, the coefficient of formal environmental regulation is 0.025 . When the intensity of public-participated environmental regulation is higher than 14 but lower than 93 , the coefficient of formal environmental regulation is 0.091 . Finally, when the intensity of public-participated environmental regulation is higher than 93, the coefficient of formal environmental regulation is 0.256 .

Results of the threshold effect and the threshold regression tests indicate pressure transmission between the public, relevant government departments, and the industrial sector. In this case, a higher intensity of public-participated environmental regulation increases pressure on relevant departments, as well as increasing the influence of formal environmental regulations on industrial-technological innovation. These results indicate that $\mathrm{H} 6$ is true. 
For instance, as public participation increases, the effectiveness of formal environmental regulations in promoting industrial-technological innovation becomes stronger. This indicates that as public awareness of environmental protection increases, the pressure on relevant government departments increases and, at the same time, formal environmental regulations can be more effective. In other words, the louder the public's voice, the more attention government departments pay to environmental issues, the more motivation they will have for more effective governance, and the environmental regulations can be more effective. However, the intensity of public-participated environmental regulations of most urban publics has not reached a level that can maximize the efficiency of formal environment-related regulations.

Table 9 summarizes the verification of hypotheses based on the preceding analysis.

Table 9. Summary of hypotheses.

\begin{tabular}{ccc}
\hline Hypotheses & True or False & Justification \\
\hline H1 & True & Indicated by the regression results of Model 2 in Table 5. \\
H2 & True & Indicated by the regression result of Model 1 in Table 5. \\
H3 & True & Indicated by the regression result of Model 3 in Table 5. \\
H4 & True & Tables 5 and 6 show a significant mediating effect. \\
H5 & True & Indicated by the regression results of Models 4, 5, and 6 in Table 5. \\
H6 & True & Table 8 indicates that H6 is true. \\
\hline
\end{tabular}

\section{Robustness Test}

This section presents a measure of the strength of formal environmental regulations by using the location entropy method.

For instance, environmental regulation (er) often refers to the government's use of compulsory means to supervise and limit pollutant emissions caused by manufacturing firms. In this section, the relative emission intensities of three pollutants in all cities are used to elicit a comprehensive measure of the strength of formal environmental regulations [43]. The three pollutants include industrial wastewater emissions, sulfur dioxide emissions, and smoke emissions. The specific formula is as follows:

$$
e r_{i, t}=\sum_{l=1}^{3} \frac{e l, i t / y i t}{\sum_{i=1}^{179}(e l, i t / y i t)}
$$

where $i$ represents the city, $l$ represents the type of emissions (e.g., industrial wastewater, industrial sulfur dioxide, and industrial smoke (dust)), and $y$ represents the industrial output value of the city. Since the study is about the intensity of urban pollution emissions, the data were reverse-processed to facilitate subsequent calculations.

Table 10 shows the test results, where the ensuing conclusions are mostly consistent with those indicated in Table 5. In Models 1, 2, and 3, stepwise regression was used to confirm the existence of the mediating effect. Moreover, it can be seen that the level of urban economic development has a significant role in promoting industrial-technological innovation. At the same time, population density hurts industrial-technological innovation. Additionally, information technology competence and the level of trade openings to the international market are both positively related to industrial-technological innovation. 
Table 10. Results of robustness regression test.

\begin{tabular}{|c|c|c|c|c|c|c|}
\hline \multirow{2}{*}{ Variables } & Model 1 & Model 2 & Model 3 & Model 4 & Model 5 & Model 6 \\
\hline & RD & er & RD & RD & RD & RD \\
\hline pres & $\begin{array}{c}0.043^{* * *} \\
(14.01)\end{array}$ & $\begin{array}{c}0.941^{* * *} \\
(3.29)\end{array}$ & $\begin{array}{c}0.043^{* * *} \\
(13.84) \\
0.001 * * \\
(2.47)\end{array}$ & $\begin{array}{c}0.042^{* * *} \\
(13.66)\end{array}$ & $\begin{array}{c}0.042 * * * \\
(13.73)\end{array}$ & $\begin{array}{c}0.042^{* * *} \\
(13.49)\end{array}$ \\
\hline er $\times \operatorname{lnlab}$ & & & & $\begin{array}{c}0.0001^{* * * *} \\
(3.53)\end{array}$ & & \\
\hline er $\times$ lninvest & & & & & $\begin{array}{c}0.00003^{* * * *} \\
(2.74)\end{array}$ & \\
\hline er $\times \operatorname{lnlab} \times$ lninvest & & & & & & $\begin{array}{c}0.000004^{* * * *} \\
(3.85)\end{array}$ \\
\hline $\operatorname{lnpgdp}$ & $\begin{array}{c}0.534^{* * *} \\
(3.63)\end{array}$ & $\begin{array}{l}-3.802 \\
(-0.28)\end{array}$ & $\begin{array}{c}0.536^{* * *} \\
(3.65)\end{array}$ & $\begin{array}{c}0.544^{* * *} \\
(3.71)\end{array}$ & $\begin{array}{c}0.529 * * * \\
(3.60)\end{array}$ & $\begin{array}{c}0.536^{* * * *} \\
(3.66)\end{array}$ \\
\hline lnpdst & $\begin{array}{c}-0.050^{* * *} \\
(-0.58)\end{array}$ & $\begin{array}{c}62.256^{* * * *} \\
(7.75)\end{array}$ & $\begin{array}{l}-0.082 \\
(-0.95)\end{array}$ & $\begin{array}{l}-0.095 \\
(-1.09)\end{array}$ & $\begin{array}{l}-0.084 \\
(-0.97)\end{array}$ & $\begin{array}{l}-0.097 \\
(-1.11)\end{array}$ \\
\hline $\operatorname{lninf}$ & $\begin{array}{c}0.384^{* * *} \\
(4.24)\end{array}$ & $\begin{array}{c}67.528^{* * * *} \\
(8.01)\end{array}$ & $\begin{array}{c}0.349^{* * * *} \\
(3.81)\end{array}$ & $\begin{array}{c}0.328^{* * * *} \\
(3.57)\end{array}$ & $\begin{array}{c}0.345^{* * * *} \\
(3.76)\end{array}$ & $\begin{array}{c}0.322^{* * * *} \\
(3.51)\end{array}$ \\
\hline lnopen & $\begin{array}{c}0.0932 * * * \\
(2.01)\end{array}$ & $\begin{array}{c}5.549 * * * * \\
(1.29)\end{array}$ & $\begin{array}{l}0.090^{*} \\
(1.95)\end{array}$ & $\begin{array}{c}0.087^{* *} \\
(1.89)\end{array}$ & $\begin{array}{l}0.089^{*} \\
(1.91)\end{array}$ & $\begin{array}{c}0.085 * * \\
(1.84)\end{array}$ \\
\hline C & $\begin{array}{c}-4.82^{* * *} \\
(-4.14)\end{array}$ & $\begin{array}{c}-434.091 \\
* * * \\
(-4.00)\end{array}$ & $\begin{array}{c}-4.598^{* * *} \\
(-3.94)\end{array}$ & $\begin{array}{c}-4.379 * * * \\
(-3.75)\end{array}$ & $\begin{array}{c}-4.526^{* * *} \\
(-3.87)\end{array}$ & $\begin{array}{c}-4.284^{* * *} \\
(-3.66)\end{array}$ \\
\hline$R^{2}$ & 0.286 & 0.175 & 0.288 & 0.290 & 0.288 & 0.290 \\
\hline $\mathrm{F}$ & $213.7^{* * * *}$ & $112.81^{* * *}$ & $179.44^{* * *}$ & $180.93^{* * *}$ & $179.77^{* * *}$ & $181.48^{* * *}$ \\
\hline$N$ & 2670 & 2670 & 2670 & 2670 & 2670 & 2670 \\
\hline
\end{tabular}

This section presents the results of an examination of the intermediate effect of the variable $e r$ between public-participated environmental regulations and industrial-technological innovations. After the bootstrap test was repeated 1000 times, the indirect effect $p$ value was 0.001 , while the confidence interval was [0.0009, 0.0004], excluding 0 (Table 11). This indicates that the indirect effect is significant.

Table 11. Results of the bootstrap test.

\begin{tabular}{ccccccc}
\hline & $\begin{array}{c}\text { Observed } \\
\text { Coed }\end{array}$ & $\begin{array}{c}\text { Bootstrap } \\
\text { std.Err. }\end{array}$ & $\mathbf{z}$ & $p$ > abs(z) & \multicolumn{2}{c}{$\begin{array}{c}\text { Normal-Based } \\
\text { [95\% conf. Internal] }\end{array}$} \\
\hline _bs_1 & 0.0024845 & 0.0007798 & 3.19 & 0.001 & 0.0009561 & 0.0040129 \\
_bs_2 & 0.0585379 & 0.0044208 & 13.24 & 0.000 & 0.0498733 & 0.0672026 \\
\hline
\end{tabular}

Number of obs = 2670; replications = 1000;_bs_1: r(ind_eff); _bs_2: r(dir_eff).

This section takes $\mathrm{er}$ as the core variable and tests whether there is a threshold for the effects of formal environmental regulations on technological innovations under different intensities of pressure from public-participated environmental regulations. The effect of $\mathrm{er}$ on industrial-technological innovation under different levels of public participation was tested. After testing, the results in Table 12 indicate that at the 5\% confidence level, there is a single threshold in this process.

Table 12. Results of the threshold effect test.

\begin{tabular}{cccccccccc}
\hline Variables & Threshold & RSS & MSE & Fstat & Prob & Crit10 & Crit5 & Crit1 & BS \\
\hline pres & Single & 8900.67 & 3.35 & 44.57 & 0.0233 & 23.88 & 32.53 & 60.39 & 300 \\
\hline
\end{tabular}

The regression results shown in Table 13 were obtained by using the threshold effect model. The results indicate that when the intensity of public-participated environmental regulation is lower than 94, the effects of formal environmental regulations on industrialtechnological innovation is not very significant. However, when the intensity of publicparticipated environmental regulations is higher than 94 , formal environmental regulations have a significant role in promoting industrial-technological innovation. 
Table 13. Results of the threshold regression test.

\begin{tabular}{cc}
\hline Variables & RD \\
\hline er ${ }^{*}$ (pres $\left.<94\right)$ & -0.0004 \\
& $(-1.57)$ \\
er*I $(94 \leq$ pres $)$ & $0.002^{* * *}$ \\
& $(4.44)$ \\
lnpgdp & $1.380^{* * *}$ \\
& $(11.19)$ \\
lnpdst & 0.880 \\
& $(1.47)$ \\
lninf & 0.136 \\
& $(1.33)$ \\
lnopen & $-0.215^{* * *}$ \\
$\mathrm{C}$ & $(-4.20)$ \\
$\mathrm{R}^{2}$ & $5.469^{* *}$ \\
$\mathrm{~F}$ & $(2.27)$ \\
& 0.17 \\
\end{tabular}

Consistent with the findings in Table 8, Table 13 indicates that when a region has higher intensities of public participation, formal environmental regulations can be more efficient in improving industrial-technological innovations. The test results of the rest of the control variables are also consistent with the regression results shown in Table 8.

\section{Conclusions and Suggestions}

This paper used the intermediary effect model and the threshold effect model to construct a panel model based on the data of 179 cities from 2005 to 2019, and then explored the nonlinear relationships between public-participated environmental regulations, formal environmental regulations, and industrial-technological innovation. The following conclusions are elicited:

(1) The public exerts pressure on relevant government departments by participating in environmental regulations. In turn, relevant departments impose environmental pressure on the industrial sector by the formal implementation of environmental regulations. In the process, the said government departments act as intermediaries and direct the public pressure to the industrial sector. Tests show a pressure effect coefficient of 0.013 , which means that, for every one-unit increase in the intensity of public-participated environmental regulation, the pressure increases the intensity of formal environmental regulations by 0.013 units. In short, formal environmental regulations play an intermediary role in the process where public-participated environmental regulations affect industrial-technological innovation. Both public-participated environmental regulation and formal environmental regulation have a promoting effect on industrial-technological innovation.

(2) The level of industrial-technological innovation is positively affected by the level of economic development. Moreover, information technology competence can also promote industrial-technological innovation, personnel exchanges, and trade cooperation, as well as improve efficiency, change traditional production and operation modes, and accelerate the transformation of knowledge into practical achievements.

(3) Labor and capital have a moderating effect on the effects of formal environmental regulations on industrial-technological innovations. All are positive adjustments.

(4) The effect of formal environmental regulations on industrial innovation has a threshold. In other words, its promoting effect depends on the intensity level of public participation. At the same time, the improvement effect of formal environmental regulations on industrial-technological innovations can be maximized when the intensity of public-participated environmental regulation is higher than 93. However, in most cities in China, public participation in environmental regulation has not reached this level. 
Based on the preceding analyses and research conclusions, the following suggestions are articulated to provide the groundwork for improving the levels of industrialtechnological innovations:

(1) To properly increase public participation in environmental issues, expand the communication channels for mass participation, enhance the publication of pollution violations, and increase information transparency in the relevant departments. For instance, setting up an environmental watchdog website, where the relevant departments can regularly check the company's pollution discharge status and publicize violations, and allowing residents to report pollution caused by enterprises. While increasing the level of mass participation, the application and practice of formal environmental regulations should be strengthened, and investments in environmental governance should be increased. Economies should be vigorously developed and industrial structure infrastructures should be improved. Information technology competence should be increased and its application in industrial production and enterprise operations should be enhanced.

(2) To increase employment rates in real economies, increase the number of laborers, provide employment guidance for students and skills training for employed personnel, combine schools with enterprises, increase the utilization rate of knowledge achievements, expand investments, and rationally allocate investment funds and resources.

Author Contributions: Conceptualization, M.Q.; methodology, M.Q. and Q.X.; software, M.Q. and Q.G.; data curation, M.Q. and Q.G.; draft preparation and writing, M.Q. and Q.X.; writing-review and editing, Q.X., M.Z.; visualization, M.Q.; supervision, Q.X., Q.G. and M.Z.; funding acquisition, Q.X. All authors have read and agreed to the published version of the manuscript.

Funding: This research was supported by the "Study on the Co-evolution Mechanism and Countermeasures of China's Producer Service Industry and Manufacturing Industry under the New Normal Economy" grant (Grant No. 16CJL027) and the "Doctoral promotion program of Suzhou Agricultural Vocational and Technical College" grant (Grant NO. BS2109).

Data Availability Statement: Data supporting the conclusions of this research are available upon request from the corresponding author.

Acknowledgments: We sincerely thank the support of the "Study on the Co-evolution Mechanism and Countermeasures of China's Producer Service Industry and Manufacturing Industry under the New Normal Economy" (Grant No. 16CJL027) and the "Doctoral promotion program of Suzhou Agricultural Vocational and Technical College" (Grant NO. BS2109). The authors also express thanks to the anonymous reviewers and editor for their valuable inputs and professional comments.

Conflicts of Interest: The authors declare no conflict of interest. 


\section{Appendix A}

Table A1. 2018 RD and pgdp data.

\begin{tabular}{|c|c|c|c|c|c|c|c|c|c|}
\hline pgdp & RD & pgdp & RD & pgdp & RD & pgdp & RD & pgdp & RD \\
\hline 7.3849 & 39.07637 & 4.2064 & 6.349755 & 3.5732 & 6.629803 & 5.52328 & 4.755061 & 4.5404 & 8.54246 \\
\hline 4.6119 & 9.3175 & 3.7028 & 5.739607 & 3.7912 & 4.488511 & 3.85952 & 4.810804 & 4.9044 & 5.595783 \\
\hline 3.855 & 8.663088 & 3.5826 & 2.200183 & 2.8536 & 5.949713 & 3.12407 & 0.864477 & 3.14158 & 1.817685 \\
\hline 4.2632 & 3.503228 & 4.901 & 5.866716 & 2.9215 & 5.230423 & 2.94049 & 1.061459 & 6.1479 & 3.045053 \\
\hline 3.3904 & 3.703868 & 3.4727 & 3.63444 & 3.7378 & 6.117984 & 3.32598 & 2.52306 & 3.7695 & 6.21417 \\
\hline 3.2705 & 5.098414 & 3.9256 & 6.317698 & 2.8327 & 1.627246 & 4.29994 & 4.60003 & 5.52193 & 6.105282 \\
\hline 3.1533 & 2.863492 & 3.4041 & 2.400282 & 4.2087 & 5.126199 & 2.92353 & 0.841813 & 5.9028 & 5.454141 \\
\hline 3.6362 & 36.593 & 3.6658 & 3.016003 & 3.1305 & 2.542623 & 2.80513 & 1.895537 & 3.7139 & 3.083409 \\
\hline 4.9397 & 5.297637 & 3.4091 & 3.546136 & 3.863 & 5.115734 & 2.71285 & 0.839148 & 6.25224 & 10.00291 \\
\hline 4.6786 & 7.835322 & 3.2844 & 2.247186 & 3.4266 & 3.503961 & 3.12557 & 1.069201 & 4.2748 & 2.984448 \\
\hline 4.3912 & 7.133128 & 3.2643 & 1.551693 & 3.4959 & 2.957794 & 3.15971 & 46.15248 & 6.194 & 5.691943 \\
\hline 3.1581 & 3.053718 & 3.1788 & 2.656678 & 3.2836 & 1.267392 & 5.51559 & 5.408604 & 4.1664 & 5.203761 \\
\hline 3.513 & 3.771915 & 3.2409 & 1.310727 & 3.3626 & 4.673696 & 5.25024 & 4.295148 & 3.26339 & 3.807159 \\
\hline 3.1994 & 2.481563 & 3.3747 & 2.807981 & 3.3956 & 3.101633 & 2.58277 & 1.142521 & 3.8217 & 2.394826 \\
\hline 3.4699 & 4.813238 & 3.9975 & 3.49188 & 3.3277 & 2.800582 & 2.67455 & 2.343275 & 6.0957 & 4.989303 \\
\hline 3.9405 & 3.329521 & 4.792 & 5.265061 & 3.4376 & 3.247221 & 2.68065 & 0.978942 & 4.7977 & 3.975221 \\
\hline 2.9514 & 2.772534 & 5.9018 & 7.123677 & 3.3505 & 1.851331 & 3.7675 & 5.027999 & 6.50521 & 4.435711 \\
\hline 3.4574 & 2.340534 & 4.0065 & 2.500738 & 3.2178 & 2.782878 & 3.7358 & 3.629802 & 3.8234 & 3.005143 \\
\hline 4.1575 & 4.826371 & 3.7942 & 2.00688 & 3.3442 & 3.23321 & 3.7939 & 4.706473 & 6.4886 & 6.645383 \\
\hline 2.6743 & 0.95403 & 4.9592 & 2.066271 & 3.2336 & 2.29528 & 4.5878 & 8.627924 & 5.1128 & 4.08181 \\
\hline 2.7015 & 3.009428 & 3.8975 & 3.177736 & 3.0425 & 1.564364 & 3.6622 & 2.145919 & 3.05125 & 4.58499 \\
\hline 3.2031 & 1.598 & 3.5148 & 2.559194 & 2.8437 & 0.820369 & 4.1864 & 2.010103 & 3.8095 & 6.762159 \\
\hline 3.7844 & 1.957057 & 3.8815 & 4.204197 & 3.0409 & 1.194781 & 3.7252 & 1.398396 & 3.0614 & 3.758835 \\
\hline 3.014 & 4.904537 & 3.5887 & 3.309413 & 3.8463 & 4.941127 & 3.7222 & 5.728322 & 3.403 & 4.161958 \\
\hline 2.829 & 1.40067 & 4.4136 & 2.647686 & 3.7297 & 3.539052 & 3.7454 & 16.1789 & 2.91066 & 8.202062 \\
\hline 2.8224 & 1.04689 & 4.0143 & 3.357889 & 3.6805 & 3.455702 & 3.3481 & 1.31915 & 4.185 & 13.45449 \\
\hline 2.8394 & 1.976388 & 3.8502 & 3.201426 & 3.1961 & 2.277536 & 3.4854 & 1.397791 & 5.2713 & 3.520047 \\
\hline 2.5648 & 1.245039 & 3.8076 & 2.055711 & 5.52108 & 7.121581 & 3.6059 & 1.176485 & 4.5237 & 5.82694 \\
\hline pgdp & RD & pgdp & RD & pgdp & RD & pgdp & RD & pgdp & RD \\
\hline 2.8423 & 3.875145 & 4.061 & 3.817702 & 4.65534 & 5.489141 & 3.6676 & 2.157488 & 3.10893 & 4.261841 \\
\hline 2.5631 & 0.765574 & 3.7151 & 7.195578 & 3.98895 & 4.567775 & 3.3749 & 1.094277 & 4.6289 & 5.390019 \\
\hline 4.0007 & 10.21672 & 3.4826 & 2.782003 & 3.65418 & 4.228986 & 3.6743 & 2.421485 & 3.6236 & 0.82 \\
\hline 7.36153 & 14.80393 & 3.7543 & 2.450528 & 2.9503 & 3.192755 & 3.6694 & 2.247736 & 3.51602 & 2.983922 \\
\hline 6.4372 & 3.734921 & 3.4831 & 3.100301 & 3.51163 & 4.160143 & 3.6005 & 0.83674 & 5.4484 & 7.042658 \\
\hline 6.1915 & 5.828683 & 3.4518 & 3.02486 & 3.38962 & 2.66128 & 3.3823 & 1.344985 & 5.0217 & 4.691368 \\
\hline 3.6215 & 3.71362 & 3.7456 & 2.56059 & 2.68113 & 3.778415 & 3.5043 & 3.002802 & 3.3663 & 0.683204 \\
\hline 6.8629 & 6.898405 & 5.1913 & 6.906573 & 3.15696 & 4.409517 & 3.3663 & 0.683204 & & \\
\hline
\end{tabular}

\section{References}

1. Lieflaender, A.K.; Bogner, F.X. Educational impact on the relationship of environmental knowledge and attitudes. Environ. Educ. Res. 2016, 24, 611-624. [CrossRef]

2. Mehmet, M.; Gülden, B. Do foreign direct investment and renewable energy consumption affect the CO2 emissions? New evidence from a panel ARDL approach to Kyoto Annex countries. Environ. Sci. Pollut. Res. 2016, 23, 21669-21681. [CrossRef]

3. Hui, W.; Huifang, L. Foreign direct investment, environmental regulation, and environmental pollution: An empirical study based on threshold effects for different Chinese regions. Environ. Sci. Pollut. Res. 2019, 26, 5394-5409. [CrossRef]

4. Qian, W.; Baolong, Y. Air pollution control intensity and ecological total-factor energy efficiency: The moderating effect of ownership structure. J. Clean. Prod. 2018, 186, 373-387. [CrossRef]

5. Michael, L.; Ellen, T.C. New practice creation: An institutional perspective on innovation. Organ. Stud. 2007, 28, 993-1012. [CrossRef]

6. Nori, T.; Stephen, P. Environmental regulation with technology adoption, learning and strategic behavior. J. Environ. Econ. Manag. 2005, 50, 447-467. [CrossRef]

7. Zhenyu, J.; Zongjun, W.; Zhubo, L. The effect of mandatory environmental regulation on innovation performance: Evidence from China. J. Clean. Prod. 2018, 203, 482-491. [CrossRef] 
8. María, D.L.; José, F.M.; Enrique, C. The potential of environmental regulation to change managerial perception, environmental management, competitiveness and financial performance. J. Clean. Prod. 2010, 18, 963-974. [CrossRef]

9. Haiyun, L.; Guiju, Z.; Yue, L. Research on the impact of environmental risk perception and public participation on evaluation of local government environmental regulation implementation behavior. Environ. Chall. 2021, 5, 1-29. [CrossRef]

10. Vinish, K. Informal regulation of pollution in a developing country: Evidence from india. Ecol. Econ. 2007, 63, 403-417. [CrossRef]

11. Libo, E.; Meimin, Y.; Chujun, W. Strategic interaction of environmental regulation and its influencing mechanism: Evidence of spatial effects among Chinese cities. J. Clean. Prod. 2021, 312, 1-16. [CrossRef]

12. Lihua, W.; Tianshu, M.; Yuanchao, B.; Sijia, L.; Zhaoqiang, Y. Improvement of regional environmental quality: Government environmental governance and public participation. Sci. Total. Environ. 2020, 717, 1-12. [CrossRef]

13. Zhiping, L.; Shixun, W.; Lihong, Y. Motivating Innovation Alliance's Environmental Performance Through Eco-innovation Investment in a Supply Chain. J. Clean. Prod. 2020, 269, 1-11. [CrossRef]

14. GRAY, W.B. The Cost of Regulation: OSHA, EPA and the Productivity Slowdown. Am. Econ. Rev. 1987, 77, 998-1006.

15. Christian, L.; Jay, P.S. Private citizen suits and public enforcement: Substitutes or complements. J. Environ. Econ. Manag. 2010, 59, 235-249. [CrossRef]

16. Wenqing, W.; Yongqian, L.; Chia-Huei, W.; Sang-Bing, T. An empirical study on government direct environmental regulation and heterogeneous innovation investment. J. Clean. Prod. 2020, 254. [CrossRef]

17. Porter, M.E. America's green strategy. Sci. Am. 1991, 264, 193-246. [CrossRef]

18. Porter, M.E.; Linder, C.V.D. Toward a new conception of the environment-competitiveness relationship. J. Econ. Perspect. 1995, 9, 97-118. [CrossRef]

19. Stefan, A.; Mark, A.C.; Stewart, E.; Pual, L. The Porter hypothesis at 20: Can environmental regulation enhance innovation and competitiveness? Rev. Environ. Econ. Policy 2013, 7, 2-22. [CrossRef]

20. Fansheng, M.; Ye, X.; Gang, Z. Environmental regulations, green innovation and intelligent upgrading of manufacturing enterprises: Evidence from China. Sci. Rep. 2020, 10. [CrossRef]

21. Ram, R.; Qile, H.; Andrew, B.; Abby, G.; David, G. Environmental regulations, innovation and firm performance: A revisit of the Porter Hypothesis. J. Clean. Prod. 2017, 155, 79-92. [CrossRef]

22. Xuehong, Z.; Xuguang, Z.; Hailing, L. The dual effects of heterogeneous environmental regulation on the technological innovation of Chinese steel enterprises-Based on a high-dimensional fixed effects model. Ecol. Econ. 2021, 188, 107-119. [CrossRef]

23. González, P.; Sarkis, J.; Adenso-Díaz, B. Environmental management system certification and its influence on corporate practices: Evidence from the automotive industry. Int. J. Oper. Prod. Manag. 2008, 28, 1021-1041. [CrossRef]

24. Samwel, M.C.; Daoping, W. The influence of technology innovation on SME performance through environmental sustainability practices in Kenya. Technol. Soc. 2020, 60, 1-12. [CrossRef]

25. Chen, X.; Pang, J.; Zhang, Z.; Li, H. Sustainability assessment of solid waste management in China: A decoupling and decomposition analysis. Sustainability 2014, 6, 9268-9281. [CrossRef]

26. Guichuan, Z.; Wendi, L.; Tingting, W.; Wenxue, L.; Liming, Z. Be regulated before be innovative? How environmental regulation makes enterprises technological innovation do better for public health. J. Clean. Prod. 2021, 303. [CrossRef]

27. Bei, X.; Ruimei, W. Effect of environmental regulation on industrial solid waste pollution in china: From the perspective of formal environmental regulation and informal environmental regulation. Int. J. Environ. Res. Public Health 2020, 17, 7798. [CrossRef]

28. Yuming, Z.; Fangming, Z.; Lilong, H. A study on the definition, classification and evolution of environmental regulation. China Popul. Resour. Environ. 2009, 6, 85-90.

29. Rubashkina, Y.; Galeotti, M.; Verdolini, E. Environmental regulation and competitiveness: Empirical evidence on the Porter Hypothesis from European manufacturing sectors. Energy Pololicy 2015, 83, 288e300. [CrossRef]

30. Ben, K.; Thomas, Z. The environmental Porter hypothesis: Theory, evidence, and a model of timing of adoption. Econ. Innov. New Technol. 2009, 18, 267-294. [CrossRef]

31. Zhenyu, J.; Zongjun, W.; Xiao, L. How environmental regulations affect corporate innovation? The coupling mechanism of mandatory rules and voluntary management. Technol. Soc. 2021, 65, 101-113. [CrossRef]

32. Lina, S.; Deqing, T.; Suling, F.; Wenting, Z. Environmental regulation, import trade, and green technology innovation. Environ. Sci. Pollut. Res. Int. 2021. [CrossRef]

33. Li, D.; Cao, C.; Zhang, L.; Chen, X.; Ren, S.; Zhao, Y. Effects of corporate environmental responsibility on financial performance: The moderating role of government regulation and organizational slack. J. Clean. Prod. 2017, 166, 1323-1334. [CrossRef]

34. Jingjing, L.; Min, Z.; Yanbo, W. Impacts of government subsidies and environmental regulations on green process innovation: A nonlinear approach. Technol. Soc. 2020, 63, 1014-1027. [CrossRef]

35. Maoliang, B.; Zhenzi, Q.; Beibei, L. Voluntary environmental regulation and firm innovation in China. Econ. Model. 2020, 89, 10-18. [CrossRef]

36. Alexandra, K.; Ioannis, G.; Aggelos, T. A typology of European countries based on innovation efficiency and technology gaps: The role of early-stage entrepreneurship. Econ.Model. 2016, 52, 477-484. [CrossRef]

37. Hui, S.; Zaenhaer, D. The Impact of Heterogeneous Environmental Regulation on Urban Environmental Pollution: Research Based on Static and Dynamic Spatial Durbin Model. East China Econ. Manag. 2021, 35, 75-82. [CrossRef]

38. Mitsutsugu, H. Environmental regulation and the productivity of Japanese manufacturing industries. Resour. Energy Econ. 2006, 28, 299-312. [CrossRef] 
39. Wanhong, L.; Yue, G.; Fang, L.; Ce, L. The effect of command-and-control regulation on environmental technological innovation in China: A spatial econometric approach. Environ. Sci. Pollut. Res. 2018, 26, 34789-34800. [CrossRef]

40. Sheoli, P.; David, W. Informal Regulation of Industrial Pollution in Developing Countries: Evidence from Indonesia. J. Political Econ. 1996, 104, 1314-1327. [CrossRef]

41. Zhonghua, C.; Jun, L.; Lianshui, L.; Xinbei, G. The effect of environmental regulation on capacity utilization in China's manufacturing industry. Environ. Sci. Pollut. Res. 2020, 27, 14807-14817. [CrossRef]

42. Lannelongue, G.; Gonzalez-Benito, J.; Quiroz, I. Environmental management and labour productivity: The moderating role of capital intensity. J. Environ. Manag. 2017, 190, 158-169. [CrossRef] [PubMed]

43. Xin, Z.; Bowen, S. The influence of Chinese environmental regulation on corporation innovation and competitiveness. J. Clean. Prod. 2016, 112, 1528-1536. [CrossRef] 